\title{
MEMAHAMI MANUSIA MELALUI DIMENSI FILSAFAT \\ (Upaya Memahami Eksistensi Manusia)
}

\author{
Aziza Aryati*
}

\begin{abstract}
Abstrak
Filsafat manusia atau antropologi filsafat merupakan bagian integral dari sistem Filsafat yang secara spesifik menyoroti hakikat atau esensi manusia. Sebagai bagian dari sistem filsafat, secara metodis ia memiliki kedudukan yang kurang lebih setara dengan cabang-cabang filsafat lainnya seperti; etika, kosmologi, epistemologi, filsafat sosial dan estetika. Semua cabang filsafat tersebut pada prinsipnya bermuara pada esensi manusia dengan menyoroti gejala dan kejadian manusia secara sintesis dan reflektif, serta memiliki ciri-ciri ekstensif, intensif dan kritis. Kalau demikian, maka dengan mempelajari filsafat manusia bererti kita dibawa ke dalam panorama pengetahuan yang sangat luas, dalam dan kritis, yang menggambarkan esensi manusia. Panorama pengetahuan seperti itu, paling tidak memiliki manfaat ganda yakni manfaat praktis dan teoritis.
\end{abstract}

Kata Kunci : filsafat manusia, esensi manusia, intensif dan kritis.

\section{Pendahuluan}

Manusia merupakan makhluk ciptaan Allah SWT yang paling sempurna, karena manusia dibekali berbagai kelebihan dibanding dengan makhluk lain, yaitu kelebihan nafsu (sifat dasar iblis), taat/patuh/tunduk (sifat dasar malaikat) dan akal (sifat keistimewaan manusia). Ketiga hal tersebut membuat manusia memiliki kedudukan yang tinggi di hadapan-Nya. Jika manusia dapat mengatur ketiganya dan dapat memposisikan diri sebagaimana yang dititahkan oleh Allah SWT, maka manusia akan memperoleh kebahagiaan abadi. Dalam Al Qur'an surat Az-Zariyat
(51) ayat 56, Allah SWT berfiman yang artinya; "Aku tidak menciptakan jin dan manusia melainkan agar mereka beribadah kepada-Ku".1 Dari tafsir tersebut terlihat jelas bahwa jin dan manusia diciptakan untuk beribadah kepada Allah. Namun, banyak dari golongan manusia yang tidak dapat melakukan sebagaimana yang diharapkan oleh sang pencipta, malah manusia berbuat sebaliknya dan mengingkari apa yang telah dikaruniakan. Itu karena manusia belum memahami betul hakikat dirinya diciptakan oleh Allah SWT.

Dengan akal, membuat manusia selalu ingin tahu tentang segala sesuatu. 
Untuk memenuhi rasa ingin tahu itu manusia menggunakan jalur pendidikan. Melalui pendidikan manusia memperoleh berbagai ilmu baru dan dapat mengembangkan ilmu tersebut. Filsafat merupakan cabang ilmu pengetahuan yang selalu menggunakan pemikiran mendalam, luas, radikal, dan berpegang pada kebijakansanaan dalam melihat suatu problem. Dengan kata lain, filsafat selalu mencoba mencari hakikat atau maksud dibalik adanya sesuatu tersebut. Dalam tulisan ini, penulis berusaha memahami manusia melalui dimensi filsafat. Untuk apa manusia hidup, bagaiman ia harus hidup, dan apa hakekat manusia hidup.

\section{A. Apa itu Filsafat?}

Sebelum lebih jauh membahas tentang hakekat manusia dalam dimensi filsafat, penulis terlebih dahulu memaparkan tentang pengertian filsafat itu sendiri. Secara etimologis, filsafat berakar dari bahasa Yunani yaitu phillein yang berarti cinta, dan shopia yang berarti kebijaksanaan. Jadi filsafat adalah "cinta akan kebijaksanaan". Kata sophia dalam pandangan filsafat lebih dari sekedar "wisdom" dalam bahasa Inggris. Sophia mengandung banyak makna. Beberepa filusuf Yunani seperti Herodotus (484-425 sM), Phytagoras (560-480 sM) dan Plato
(427-347 sM) menunjukkan keragaman pengertian ini. Herodotus menggunakan kata philosophein dalam upaya untuk menemukan sesuatu. Dalam pengertian ini filsafat diberi arti rasa cinta untuk mengetahui dan memuaskan aspek kognitifnya. Sementara Phytagoras mengaitkan sophia dengan kontemplasi. Sophia bagi Phytagoras adalah "pengetahuan hasil kontemplasi". Dengan pengertian itu murid Plato ini ingin membedakan antara pengetahuan hasil kontemplasi dengan pengetahuan yang bersifat teknis dan instrumentalistik yang dimiliki oleh para pelaku bisnis dan atlet. ${ }^{2}$ Plato, sebagaimana dipaparkan oleh Andre Ata Ujan, lebih jauh menunjukkan hakekat filsafat sebagai hasil kontemplasi dalam lima karakter berikut. ${ }^{3}$ Pertama, dapat bertahan terhadap diskusi kritis. Artinya kegiatan utama dari filsafat adalah mengkaji secara kritis tentang segala hal. Dengan kajian itu diharapkan terjadi pertanggungjawaban rasional. Kedua, menggunakan metode dialektis. Dengan metode ini filsafat bergerak secara bertahap, yakni mengkritik pandanganpandangan yang ada, setelah itu membangun pandangan baru yang didukung dengan argumen yang lebih kuat. Ketiga, berusaha mencapai realitas yang terdalam. Filsafat menganalisa halhal terdalam dari kenyataan. Ia tidak 
berhenti pada fakta empiris, melainkan berusaha untuk menemukan kebenaran yang terdalam. Filsafat mencari pengetahuan yang sejati serta hal yang hakiki dari realitas. Karena itulah filsafat bersifat metaempiris. Keempat, filsafat bertujuan untuk mengangkap tujuan ideal realitas. Bagi Plato memahami kebenaran berarti juga memahami Idea tentang kebenaran yang dicari oleh manusia. Idea tentang kebenaran dilihat sebagai realitas tertinggi bagi manusia. Kelima, mengetahui bagaimana harus hidup sebagai manusia. Dalam butir ini filsafat dikaitkan dengan suatu pengetahuan yang benar tentang cara hidup sebagai manusia. ${ }^{4}$

Dari berbagai karakter di atas, filsafat dapat didefinisikan dalam tiga hal. Pertama, filsafat sebagai hasil perenungan. Dalam pengertian ini filsafat merupakan perenungan terhadap hasil permanungan atau ide-ide yang ada. Perenungan ini adalah sejenis percakapan yang dilakukan dengan diri sendiri atau dengan orang lain. Kedua, sebagai kritik. Dalam pengertian ini filsafat berusaha mengerti, membedakan dan mengambil keputusan. ${ }^{5}$ Ketiga, filsafat sebagai ilmu yang berusaha mencari kebenaran secara metodis, sistematis, rasional dan radikal melampaui kebenaran dan pertanggungjawaban. Sebagai sebuah ilmu filsafat selalu berusaha untuk bertanya dan mempertanyakan. Tujuannya adalah untuk menemukan kebenaran dan sebab musabab yang terdalam dari segala hal. ${ }^{6}$

Kemudian dari pendekatan etimologis tersebut, dapat disimpulkan bahwa filsafat berarti pengetahuan mengenai pengetahuan, akar dari pengetahuan atau pengetahuan yang terdalam. ${ }^{7}$ Secara terminologis, banyak sekali pendapat-pendapat yang berkenaan dengan pengertian filsafat. Tidak ada pengertian yang secara pasti, tetapi berikut beberapa pengertian yang penulis dapat dari beberapa sumber. Filsafat adalah ilmu pengetahuan yang amat luas (komprehensif) yang berusaha untuk memahami persoalan-persoalan yang timbul didalam keseluruhan ruang lingkup pengalaman manusia. ${ }^{8}$ Filsafat adalah ilmu yang mempelajari dengan sungguh-sungguh tentang hakekat kebenaran sesuatu. ${ }^{9}$

Filsafat adalah daya upaya manusia dengan akal budinya untuk memahami, mendalami dan menyelami secara radikal, dan integral serta sistematik mengenai ketuhanan, alam semesta dan manusia sehingga dapat menghasilkan pengetahuan tentang bagaimana 
hakekatnya yang dapat dicapai akal manusia dan bagaimana sikap manusia seharusnya setelah mencapai pengetahua tersebut. ${ }^{10}$

\section{B. Eksistensi Manusia Sebagai Individu}

Pembahasan ini mengutip tulisan Zaenal Abidin ketika membahs tentang filsafat eksistensi Soren Aabye Kierkegaard (1883-1855). Tulisannya menitikberatkan pada pandangannya tentang eksistensi manusia dan tahaptahap perkembangannya. ${ }^{11}$ Eksistensi manusia dan tahap-tahap perkembangannya sebagai berikut;

\section{Tahap Estetis}

Tahap estetis adalah tahap di mana orientasi hidup manusia sepenuhnya diarahkan untuk mendapatkan kesenangan. Pada tahap ini manusia dikuasai oleh naluri-naluri seksual (libido), oleh prinsip-prinsip kesenangan yang hedonistik, dan biasanya bertindak menurut suasana hati (mood). Kierkegaard mengambil sosok Don Juan sebagai model manusia estetis. Don Juan hidup sebagai hedonis yang tidak mempunyai komitmen dan keterlibatan apapun dalam hidupnya. Ia tidak mempunyai passion dalam menyikapi dan menindaklanjuti suatu persoalan. Tidak ada cinta dan tidak ada ketertarikan untuk mengikatkan diri dalam suatu perkawinan, selain keinginan untuk berpetualang dengan wanita. Cinta dan wanita adalah hambatan untuk petualangan dan untuk kebebasan dan oleh sebab itu bisa dianggap mengurangi kesenangan. Modela manusia estetis hidup untuk dirinya sendiri, untuk kesenangan dan kepentingan pribadinya.

Manusia estetis pun adalah manusia yang hidup tanpa jiwa. Ia tidak mempunyai akar dan isi di dalam jiwanya. Kemauannya adalah menginkatkan diri pada kecenderungan masyarakat dan zamannya. Yang menjadi trend dalam masyarakat menjadi petunjuk hidupnya dan oleh sebab itu ia ikuti secara seksama. Namun kesemuanya itu tidak dilandasi oleh passion apapun, selain keinginan untuk sekedar mengetahui dan mencoba. Hidupnya tidak mengakar dalam, karena dalam pandangannya pusat kehidupan itu ada di dunia luar. Panduan hidup dan moralitasnya ada pada masyarakat dan kecenderungan zamannya.

Manusia estetis bisa mewujud pada siapa saja, termasuk pada para filusuf, ilmuwan, sejauh mereka tidak memiliki passion, tidak mempunyai antusiasme, komitmen dan keterlibatan tertentu dalam hidupnya. Jiwa estetis mereka tampak dari pretensi mereka untuk menjadi "penonton obyektif" kehidupan. Mereka hanya mengamati dan mendeskripsikan setiap kejadian yang mereka amati dan 
alami dalam kehidupan tanpa berusaha untuk melibatkan diri ke dalamnya. Manusia estetis tidak tahu lagi apa yang sebetulnya diinginkannya, karena hidupnya tergantung pada mood dan trend dalam masyarakat dan zamannya. Yang pada akhirnya model manusia setetis ini, hidupnya hampir tidak bisa lagi menentukan pilihan karena semakin banyak alternatif yang ditawarkan masyarakat dan zamannya. Jalan keluarnya hanya ada dua; bunuh diri (atau, bisa juga lari dalam kegilaan) atau masuk dalam tingkatan hidup yang lebih tinggi, yakni tingkatan etis. ${ }^{12}$

\section{Tahap Etis}

Memilih hidup dalam tahap etis berarti mengubah pola hidup yang semula estetis menjadi etis. Ada semacam "pertobatan" di sini, di mana individu mulai menerima kebajikan-kebajikan moral dan memilih untuk mengikatkan diri kepadanya. Prinsip kesenangan (hedonisme) dibuang jauh-jauh dan sekarang ia menerima dan menghayati nilai-niulai kemanusiaan yang bersifat universal. Sudah mulai ada passion dalam menjalani kehidupan berdasarkan nilainilai kemanusiaan yang dipilihnya secara bebas. Perkawinan merupakan langkah perpindahan dari eksistensi estetis ke eksistensi etis. Prinsip kesenangan dan naluri seksual tidak diproyeksikan langsung dalam petualangannya dengan wanita, melainkan disublimasikan untuk tugas-tugas kemanusiaan. Hidup manusia etis tidak untuk kepentingannya sendiri, melainkan demi nilai-nilai kemanusiaan yang jauh lebih tinggi.

Jiwa individu etis mulai terbentuk, sehingga hidupnya tidak lagi tergantung pada masyarakat dan zamannya. Akarakar kepribadiannya cukup tangguh dan kuat. Akar kehidupannya ada dalam dirinya sendiri dan pedoman hidupnya adalah nilai-nilai kemanusiaan yang lebih tinggi. Maka, dengan berani dan percaya diri ia akan mengatakan "tidak" pada setiap trend yang tumbuh dan berkembang dalam masyarakat dan zamannya, sejauh trend itu tidak sesuai dengan "suara hati" dan kepribadiannya. Manusia etis pun akan sanggup menolak tirani atau kuasa dari luar, baik yang bersifat represif maupun nonrepresif, sejauh tirani atau kuasa itu tidak sejalan dengan apa yang diyakininya. ${ }^{13}$

\section{Tahap Religius}

Keotentikan hidup manusia sebagai subyek atau "aku" baru akan tercapai kalau individu dengan "mata tertutup" lompat dan meleburkan diri dalam realitas Tuhan. Lompatan dari tahap etis 
ke tahap religius jauh lebih sulit dan sublim daripada lompatan dari tahap estetis ke tahap etis, maka secara rasional kita bisa mempertimbangkan segala konsekuensi yang mungkin akan kita hadapi, sedangkan lompatan dari tahap etis ke tahap religius nyaris tanpa pertimbangan-pertimbangan rasional. Tidak dibutuhkan alasan atau pertimbangan rasional dan ilmiah di sini. Yang diperlukan hanyalah keyakinan subyektif yang berdasarkan pada iman.

Hidup dalam Tuhan adalah hidup dalam subyektivitas transenden, tanpa rasionalisasi dan tanpa ikatan pada sesuatu yang bersifat duniawi atau mundane. Individu yang hendak memilih jalan religius tidak bisa lain kecuali berani menerima subyektivitas transendennya itu- subyektivitas yang hanya mengikuti jalan Tuhan dan tidak lagi tertarik baik pada nilai-nilai kemanusiaan yang bersifat universal (eksistensi etis) maupun pada tuntutan pribadi dan masyarakat atau zamannya (tahap estetis). ${ }^{14}$

\section{Hakekat Manusia dalam Pandangan Filsafat}

Sabagaimana telah sedikit di utarakan di awal tadi, manusia merupakan makhluk yang sangat unik. Upaya pemahaman hakekat manusia sudah dilakukan sejak dahulu. Namun, hingga saat ini belum mendapat pernyataan yang benar-benar tepat dan pas, dikarenakan manusia itu sendiri yang memang unik, antara manusia satu dengan manusia lain berbeda-beda. Bahkan orang kembar identik sekalipun, mereka pasti memiliki perbedaaan. Mulai dari fisik, ideologi, pemahaman, kepentingan dan lain-lain. Semua itu menyebabkan suatu pernyataan belum tentu pas untuk di amini oleh sebagian orang.

Para ahli pikir dan ahli filsafat memberikan sebuten kepada manusia sesuai dengan kemampuan yang dapat dilakukan manusia di bumi ini; ${ }^{15}$

a. Manusia adalah Homo Sapiens, artinya makhluk yang mempunyai budi,

b. Manusia adalah Animal Rational, artinya binatang yang berpikir,

c. Manusia adalah Homo Laquen, artinya makhluk yang pandai menciptakan bahasa dan menjelmakan pikiran manusia dan perasaan dalam kata-kata yang tersusun,

d. Manusia adalah Homo Faber, artinya makhluk yang terampil. Dia pandai membuat perkakas atau disebut juga Toolmaking Animal yaitu binatang yang pandai membuat alat,

e. Manusia adalah Zoon Politicon, yaitu makhluk yang pandai bekerjasama, bergaul dengan orang lain dan 
mengorganisasi diri untuk memenuhi kebutuhan hidupnya,

f. Manusia adalah Homo Economicus, artinya makhluk yang tunduk pada prinsip-prinsip ekonomi dan bersifat ekonomis,

g. Manusia adalah Homo Religious, yaitu makhluk yang beragama.

Dr. M. J. Langeveld seorang tokoh pendidikan bangsa Belanda, memandang manusia sebagai Animal Educadum dan Animal Educable, yaitu manusia adalah makhluk yang harus dididik dan dapat dididik. Oleh karena itu, unsur rohaniah merupakan syarat mutlak terlaksananya program-program pendidikan. Penulis akan mencoba memaparkan apa sebenarnya hakekat manusia yang dirangkum dari beberapa sumber bacaan. Ilmu yang mempelajari tentang hakekat manusia disebut Antropologi Filsafat. ${ }^{16}$ Berikut pembahasan mengenai manusia:

1. Masalah Rohani dan Jasmani

Setidaknya terdapat empat aliran pemikiran yang berkaitan tentang masalah rohani dan jasmani (sudut pandang unsur pembentuk manusia) yaitu: Aliran serba zat, aliran serba ruh, aliran dualisme, dan aliran aksistensialisme.

a. Aliran Serba zat (faham materialisme), aliran serba zat ini mengatakan yang sungguh-sunguh ada itu adalah zat atau materi, alam ini adalah zat atau materi dan manusia adalah unsur dari alam, maka dari itu manusia adalah zat atau materi. ${ }^{17}$ Manusia ialah apa yang nampak sebagai wujudnya, terdiri atas zat (darah, daging, tulang). ${ }^{18}$ Jadi, aliran ini lebih berpemahaman bahwa esensi manusia adalah lebih kepada zat atau materinya. Manusia bergerak menggunakan organ, makan dengan tangan, berjalan dengan kaki, dan lainlain. Semua serba zat atau meteri. Berdasar aliran ini, maka dalam pendidikan manusia harus melalui proses mengalami atau praktek (psikomotor).

b. Aliran Serba Ruh, aliran ini diberi nama aliran Idealisme. Aliran ini berpendapat bahwa segala hakikat sesuatu yang ada di dunia ini adalah ruh, juga hakekat manusia adalah ruh. ${ }^{19}$ Ruh disini bisa diartikan juga sebagai jiwa, mental, juga rasio/akal. Karena itu, jasmani atau tubuh (materi, zat) merupakan alat jiwa untuk melaksanakan tujuan, keinginan dan dorongan jiwa (rohani, spirit, ratio) manusia. ${ }^{20}$ Jadi, aliran ini beranggapan bahwa yang menggerakkan tubuh itu adalah ruh atau jiwa. Tanpa ruh atau jiwa maka jasmani, raga atau fisik manusia akan mati, sia-sia dan tidak berdaya sama sekali. Dalam 
pendidikan, maka tidak hanya aspek pengalaman saja yang diutamakan, faktor dalam seperti potensi bawaan (intelegensi, rasio, kemauan dan perasaan) memerlukan perhatian juga.

c. Aliran Dualisme, aliran ini menganggap bahwa manusia itu pada hakekatnya terdiri dari dua substansi, yaitu jasmani dan rohani. ${ }^{21}$ Aliran ini melihat realita semesta sebagai sintesa kedua kategori animate dan inanimate, makhluk hidup dan benda mati. Demikian pula manusia merupakan kesatuan rohani dan jasmani, jiwa dan raga.22 Misalnya ada persoalan: dimana letaknya mind (jiwa, rasio) dalam pribadi manusia. Mungkin jawaban umum akan menyatakan bahwa ratio itu terletak pada otak. Akan tetapi akan timbul problem, bagaiman mungkin suatu immaterial entity (sesuatu yang non-meterial) yang tiada membutuhkan ruang, dapat ditempatkan pada suatu materi (tubuh jasmani) yang berada pada ruang wadah tertentu. ${ }^{23}$ Jadi, aliran ini meyakini bahwa sesungguhnya manusia tidak dapat dipisahkan antara zat/raga dan ruh/jiwa. Karena pada hakekatnya keduanya tidak dapat dipisahkan. Masing-masing memiliki peranan yang sama-sama sangat vital. Jiwa tanpa ruh ia akan mati, ruh tanpa jiwa ia tidak dapat berbuat apa-apa. Dalam pendidikan pun, harus memaksimalkan kedua unsur ini, tidak hanya salah satu saja karena keduanya sangat penting.

d. Aliran Eksistensialisme, aliran filsafat modern ini berpikir tentang hakekat manusia yang merupakan eksistensi atau perwujudan sesungguhnya dari manusia. Jadi intinya hakikat manusia itu, apa yang menguasai manusia secara menyeluruh. Di sini manusia dipandang dari serba zat, serba ruh atau dualisme dari kedua aliran itu, tetapi memandangnya dari segi eksistensi manusia itu sendiri di dunia. ${ }^{24}$

2. Sudut Pandang Antropologi

Dari segi antropologi terdapat tiga sudut pandang hakekat manusia, yaitu manusia sebagai makhluk individu, makhluk sosial dan makhluk susila. Berikut penjelasan dari ketiganya:

a. Manusia Sebagai Makhluk Individu (Individual Being). Dalam bahasa filsafat dinyatakan self-existence adalah sumber pengertian manusia akan segala sesuatu. Self-existence ini mencakup pengertian yang amat luas, terutama meliputi: kesadaran adanya diri diantara semua relaita, self-respect, self-narcisme, egoisme, martabat kepribadian, perbedaan dan persamaan dengan pribadi lain, khususnya kesadaran akan potensipotensi pribadi yang menjadi dasar bagi self-realisasi. Manusia sabagai individu memiliki hak asasi sebagai kodrat alami 
atau sebagi anugrah Tuhan kepadanya. Hak asasi manusia sebagai pribadi itu terutama hak hidup, hak kemerdekaan dan hak milik.25 Disadari atau tidak menusia sering memperlihatkan dirinya sebagai makhluk individu, seperti ketika mereka memaksakan kehendaknya (egoisme), memecahkan masalahnya sendiri, percaya diri, dan lain-lain. Menjadi seorang individu manusia mempunyai ciri khasnya masing-masing. Antara manusia satu dengan yang lain berbeda-beda, bahkan orang yang kembar sekalipun, karena tidak ada manusia di dunia ini yang benar-benar sama persis. Fisik boleh sama, tetapi kepribadian tidak.

b. Manusia Sebagai Makhluk Sosial (Sosial Being). Telah kita ketahui bersama bahwa manusia tidak dapat hidup sendirian, manusia membutuhkan manusia lain agar bisa tetap exsis dalam menjalani kehidupan ini, itu sebabnya manusia juga dikenal dengan istilah makhluk sosial. Keberadaanya tergantung oleh manusia lain. Esensi manusia sebagai makhluk sosial ialah adanya kesadaran manusia tentang status dan posisi dirinya dalam kehidupan bersama dan bagaimana tanggung jawab dan kewajibannya di dalam kebersamaan itu. Adanya kesadaran interdependensi dan saling membutuhkan serta dorongan-dorongan untuk mengabdi sesamanya adalah asas sosialitas itu. Kehidupan individu di dalam antar hubungan sosial memang tidak usah kehilangan identitasnya. Sebab, kehidupan sosial adalah realita sama rielnya dengan kehidupan individu itu sendiri. Individualitas itu dalam perkembangan selanjutnya akan mencapai kesadaran sosialitas. Tiap manusia akan sadar akan kebutuhan hidup bersama segera setelah masa kanak-kanak yang egosentris berakhir. ${ }^{26}$ Seorang guru dalam kegiatan pembelajaran perlu menanamkan kerjasama kepada peserta didiknya, agar kesadaran sosial itu dapat tumbuh dan berkembang dengan baik. Hal tersebut dapat dicapai dengan penerapan strategi dan metode yang tepat, juga dengan pemberian motivasi tentang kebersamaan.

c. Manusia Sebagai Makhluk Susila (Moral Being). Asas pandangan bahwa manusia sebagai makhluk susila bersumber pada kepercayaan bahwa budi nurani manusia secara apriori adalah sadar nilai dan pengabdi norma-norma. Kesadaran susila (sense of morality) tak dapat dipisahkan dengan realitas sosial, sebab, justru adanya nilai-nilai, efektivitas nilai-nilai, berfungsinya nilai-nilai hanyalah di dalam kehidupan sosial. Artinya, kesusilaan atau moralitas adalah fungsi sosial. Asas kesadaran nilai, asas 
moralitas adalah dasar fundamental yanng membedakan manusia dari pada hidup makhlukmakhluk alamiah yang lain. Rasio dan budi nurani menjadi dasar adanya kesadaran moral itu. ${ }^{27}$

Ketiga esensi di atas merupakan satu kesatuan yang tidak terlepaskan dari diri manusia, tinggal ia sadar atau tidak. Beberapa individu mempunyai kecenderungan terhadap salah satu esensi itu. Ada yang cenderung esensi pertama yang lebih menonjol, ada yang kedua dan ada yang ketiga. Semua tergantung pemahaman dan pendidikan yang dialami oleh si individu tersebut. Fungsi pendidikan adalah mengembangkan ketiganya secara seimbang. Agar manusia dapat menempatkan diri sesuai situasi dan kondisi yang sedang dialami. Sesuatu yang berlebihan atau malah kurang itu tidak baik, jadi yang terbaik itu adalah seimbang.

3. Pandangan Freud tentang Struktur Jiwa (Kepribadian). ${ }^{28}$ Menurut Freud (ahli ilmu jiwa), struktur jiwa (kepribadian) terbentuk oleh tiga tingkatan atau lapisan, yaitu bagian dasar (das Es), bagian tengah (das Ich) dan bagian atas (das Uber ich).

a. Bagian Dasar atau das Es (the Id), bagian ini merupakan bagian paling dasar yaitu berkenaan dengan hasrat-hasrat atau sumber nafsu kehidupan. Semua tuntutan das Es semata-mata demi kepuasan, tanpa memperhatikan nilai baik-buruk. Das Es ini merupakan prototype dari sifat individualistis manusia, egoistis, a-sosial bahkan a-moral. Dan ketika manusia semata-mata mengikuti dorongan das Es yang demikian tadi, maka sesungguhnya manusia tidak ada bedanya dengan makhluk alamiah lain.

b. Bagian Tengah atau das Ich (aku), bagian ini terletak ditengah antara das Es dan das Uber Ich. Menjadi penengah antara kepentingan das Es dan tujuan-tujuan das Uber Ich. Das Ich ini bersifat objektif dan realistis, sehingga pribadi seseorang dapat berjalan dengan seimbang dan harmonis. Sesuai letaknya, das Ich ini lebih sadar norma dibanding das Es. Kesadaran das Ich yang bersifat ke-aku-an ini lebih bersifat social, sehingga das Ich dapat disamakan sebagai aspek sosial kepribadian manusia.

c. Bagian Atas atau das Uber Ich (superego), bagian jiwa yang paling tinggi, sifatnya paling sadar norma, paling luhur. Bagian ini yang paling lazim disamakan dengan budi nurani. Setiap motif, cita-cita dan tindakan das Uber Ich selalu didasarkan pada asas-asas normative. Superego ini selalu menjunjung tinggi nilai-nilai, baik nilai etika maupun nilai religious. Dengan demikian, superego adalah bagian jiwa yang paling sadar terhadap makna kebudayaan, 
membudaya dalam arti terutama sadar nilai moral, watak superego ialah susila.

\section{Tujuan Hidup Manusia}

Segala sesuatu yang ada dalam kehidupan ini pasti mempunyai asal-usul dan tujuan keberadaanya, begitu juga manusia. Asala mula dan tujuan hidup manusia merupakan substansi yang sulit dijelaskan. Karena akal manusia sangat terbatas untuk mencapai pada substansi tersebut. Pikiran manusia tidak pernah mampu menjelaskan secara terperinci tentang substansi asal-mula tersebut. Mekipun demikian, pikiran manusia dapat dipastikan mampu secara logis menyimpulkan dan menilai bahwa hakekat asal mula itu hanya ada satu, bersifat universal, dan berada di dunia metafisis, karena itu bersifat absolut dan tidak mengalami perubahan serta sebagai sumber dari segala sumber yang ada. ${ }^{29}$ Ketika manusia menyadari bahwa asal mula dan tujuan hidup hanya satu, bersifat universal dan berada di dunia metafisis, maka pernyataan itu merujuk pada keberadaan Tuhan. Dalam agama Islam, manusia meyakini bahwa ia berasal dari Allah SWT dan nantinya akan kembali kepada-Nya juga. Akal pikiran manusia dapat memastikan bahwa kehidupan ini berawal dari causa prima (Tuhan) dan pada akhirnya kembali kepada causa prima (Tuhan) pula. ${ }^{30}$ Jadi, jika demikian adanya maka dalam Islam setidaknya manusia mempunyai beberapa tujuan. Tujuan hidup manusia paling sedikit ada empat macam; beribadah, menjadi khalifah Allah di muka bumi (yang baik dan sukses tentunya), memperoleh kesuksesan (kebaikan, kebahagiaan dan keberuntungan) di dunia dan di akhirat, dan mendapat ridho Allah. ${ }^{31}$

\section{Hakikat dan Martabat Manusia}

Tahap religius sebagaimana telah dijelaskan di atas, dalam bagian ini lebih diarahkan pada hakekat dan martabat manusia berdasarkan agama tauhid. Manusia dalam ajaran agama Tauhid tersusun dari dua unsur yaitu materi dan nonmateri, jasmani dan rohani. Tubuh manusia mempunyai daya fisik atau jasmani, yaitu daya mendengar, daya melihat, daya merasa, daya meraba, daya menciun dan daya gerak, baik ditempat seperti menggerakkan tangan, kepala, kaki, mata, dan sebagainya. Adapun roh atau jiwa yang berasal dari nonmateri yang biasa disebut dengan an-nafs memiliki tiga daya; (1) daya pikir yang disebut akal berpusat di kepala, (2) daya rasa di dada berpusat di kalbu dan (3) daya nafsu berpusat di perut. Ketika daya 
dimaksud akan mengalami perkembangan dan penurunan sesuai dengan kemampuan manusia dalam mengolah daya-daya dimaksud.

Pertama,daya pikir atau akal yang berpusat di kepala dalam Islam dipertajam melalui perenungan alam semesta dan kejadian-kejadian yang ada di alam ini. Oleh karena itu, para filosof Muslim mempertajamnya dengan melalui dorongan ayat-ayat kauniyyah; ayat-ayat mengenai alam kosmos, yang mengandung perintah kepada manusia agar memikirkan dan meneliti alam sekitarnya. ${ }^{32}$

Kedua, daya rasa di kalbu yang berpusat di dada dipertajam melalui ibadah (shalat, zakat, puasa, dan haji). Hal ini berarti intisari dari semua ibadah adalah mendekatkan diri kepada Allah SWT. Yang Maha Suci hanya bisa didekati melalui roh yang suci pula. Ibadah merupakan sarana untuk mensucikan roh atau jiwa manusia. Oleh karena itu, makin banyak manusia melakukan ibadah secara ikhlas, maka semakin suci pula roh atu jiwanya. $^{33}$ Seorang penulis Barat Tor Andre mengatakan bahwa eksistensi manusia, yakni yang memiliki corak kesediaan menolong orang, berterima kasih kepad orang tua, sikap damai, sikap tidak kikir, tidak melakukan zina, tidak melakukan sumpah palsu, tidak tuli dan tidak buta terhadap teguran untuk kebaikan, menjadi teladan baik bagi manusia dan cinta sesama manusia. Oleh karena itu, peradaban Islam tidak hanya berdasar pada penalaran akal saja melainkan melalui budi pekerti luhur dan akhlak mulia. ${ }^{34}$

Ketiga, daya nafsu yang berpusat di perut akan meningkat kekuatannya bila nafsu itu diikuti kemauannya. Manusia yang mengikuti hawa nafsu yang demikian, akan jatuh derajatnya lebih rendah dari mahluk binatang. Sebaliknya, daya nafsu yang memperoleh bimbingan dari hati nuraninya melalui keimanannya atau manusia yang mampu mengendalikan hawa nafsunya akan menjadi lebih tinggi derajatnya dari mahluk lainnya termasuk termasuk Malaikat.

Konsep manusia menurut pandangan Islam sebagaimana disebutkan di atas, berbeda dari konsep manusia menurut ajaran sekulerisme. Manusia menurut konsep sekularisme adalah manusia tersusu dari tubuh dan roh. Roh dalam konsep ini adalah daya yang berfikir dalam diri manusia. Daya rasa di dada yang erat hubungannya dengan hati nurani tidaklah menonjol. Daya pikir di sini banyak bergantung pada panca indera dan pancaindera berhubungan dengan hal-hal yang bersifat materi karena otak 
yang berbentuk fisik. Oleh karena itu, dengan meninggalnya manusia maka selesailah seluruh riwayatnya. Tidak ada hidup kedua, tidak ada perhitungan setelah mati, yang ada hanya kehidupan materi.

Berdasrkan uraian di atas (tahap religius) dapat dikatakan bahwa keyakinan keagamaan menyebabkan pengaruh positif yang luar biasa; antara lain:

1). Keyakinan kegamaan mampu menciptakan kebahagiaan dan kegembiraan. Penciptaan yang dimaksud adalah sesuatu yang memiliki sasaran yang dirahmati oleh Allah SWT. Oleh karenanya, manusia dibolehkan memanfaatkan ilmu dan teknologi selama tidak merusak norma-norma Ilahiyah yang berlaku kepada manusia.

2). Keyakinan keagamaan mampu mewujudkan kemasyarakatan yang sehat, yaitu menghargai hak asasi manusia, menghargai aturan-aturan dan pembatasan-pembatasan, menganggap keadilan sesuatu yang suci dan menawarkan rasa cinta kepada orang lain.

3). Keyakinan keagamaan mampu mewujudkan dalam diri manusia kekuatan untuk bertahan dan menjelmakan kepahitan menjadi rasa manis. Orang yang beriman mengetahui bahwa segala sesuatu di dunia ini berada dalam pola aturan tertentu yang disebut sunatullah atau hukum alam. ${ }^{35}$

\section{E. Hubungan Antara Filsafat, Pendidikan dan Manusia}

Dari pemaparan di atas, ternyata menusia benar-benar merupakan makhluk yang unik. Manusia memiliki berbagai dimensi dasar, baik secara pribadi, jiwa, kelompok, dan lain-lain. Semua itu bercampur aduk menjadi potensi dasar atau bawaan manusia, sehingga disadari atau tidak, manusia telah mengembangkan potensi tersebut, baik secara maximal atau tidak, dengan baik atau buruk. Semuanya tergantung manusia itu sendiri dan lingkungan yang mempengaruhinya. Kaitanya dengan hal tersebut, dengan akal manusia yang bisa dikatakan jenius, manusia dapat menemukan jalan untuk mengembangkan potensi-potensi mereka dengan baik. Yaitu dengan pendidikan. Manusia mulai sadar akan arti penting pendidikan bagi kehidupan mereka.

Dalam sub ini, penulis mencoba mencari keterkaitan antara pendidikan dengan manusia. Atau, apakah arti penting pemahaman tentang hakekat manusia tadi terhadap proses pendidikan. Pendidikan adalah usaha sadar, terencana, 
sistematis dan berkelanjutan untuk mengembangkan potensi-potensi bawaan manusia, memberi sifat dan kecakapan, sesuai dengan tujuan pendidikan. ${ }^{36}$ Pendidikan adalah bagian dari suatu proses yang diharapkan untuk mencapai suatu tujuan. ${ }^{37}$ Melihat pengertian di atas, dapat disimpulkan bahwa hubungan pendidikan dengan manusia itu sangat erat. Adanya pendidikan untuk mengembangkan potensi manusia, menuju manusia yang lebih baik, dan dapat mengemban tugas dari Allah SWT. Berbicara tentang pendidikan, berarti membicarakan tentang hidup dan kehidupan manusia. Sebaliknya, berbicara tentang kehidupan manusia berarti harus mempersoalkan masalah kependidikan. ${ }^{38}$ Jadi, antara manusia dan pendidikan terjalin hubungan kausalitas. Karena manusia, pendidikan mutlak ada; dan karena pendidikan, manusia semakin menjadi diri sendiri sebagai manusia yang manusiawi. 39

Manusia merupakan subyek pendidikan, tetapi juga sekaligus menjadi objek pendidikan itu sendiri. Pedagogik tanpa ilmu jiwa, sama dengan praktek tanpa teori. Pendidikan tanpa mengerti manusia, berarti membina sesuatu tanpa mengerti untuk apa, bagaimana, dan mengapa manusia dididik. Tanpa mengerti atas manusia, baik sifat-sifat individualitasnya yang unik, maupun potensi-potensi yang justru akan dibina, pendidikan akan salah arah. Bahkan tanpa pengertian yang baik, pendidikan akan memperkosa kodrat manusia.40 Esensia kepribadian manusia, yang tersimpul dalam aspek-aspek: individualitas, sosialitas dan moralitas hanya mungkin menjadi relita (tingkah laku, sikap) melalui pendidikan yang diarahkan kepada masing-masing esensia itu. Harga diri, kepercayaan pada diri sendiri (selfrespect, self-reliance, self confidence) rasa tanggung jawab, dan sebagainya juga akan tumbuh dalam kepribadian manusia melalui proses pendidikan. Jadi, hubungan antara filsafat, pendidikan dan manusia secara singkat adalah sebagai berikut; filsafat digunakan untuk mencari hakekat manusia, sehingga diketahui apa saja yang ada dalam diri manusia. Hasil kajian dalam filsafat tersebut oleh pendidikan dikembangkan dan dijadikannya (potensi) nyata berdasarkan esensi keberadaan manusia. Sehingga dihasilkan manusia yang sejati, yang utuh sebagaimana dititahkan oleh Allah SWT.

\section{F. Kesimpulan}

Filsafat manusia menyoroti gejala dan kejadian manusia secara sintesis dan reflektif, serta memiliki ciri-ciri ekstensif, intensif dan kritis. Kalau demikian, maka 
dengan mempelajari filsafat manusia bererti kita dibawa ke dalam panorama pengetahuan yang sangat luas, dalam dan kritis, yang menggambarkan esensi manusia. Panorama pengetahuan seperti itu, paling tidak memiliki manfaat ganda yakni manfaat praktis dan teoritis.

Secara praktis filsafat manusia bukan saja berguna untuk mengetahui apa dan siapa manusia secara menyeluruh, melainkan juga untuk mengetahui siapakan sesungguhnya diri kita di dalam pemahaman tentang manusia yang menyeluruh itu. Sedangklan secara teoritis, filsafat manusia mampu memberikan kepada kita pemahaman yang esensial tentang manusia, sehingga pada gilirannya, kita bisa meninjau secara kritis asumsi-asumsi yang tersembunyi dibalik teori-teori yang terdapat di dalam ilmu-ilmu tentang manusia.

Dari pembahasan di atas, maka dapat penulis simpulkan sebagai berikut; filsafat berakar dari bahasa Yunani yaitu phillein yang berarti cinta, dan shopia yang berarti kebijaksanaan. Jadi filsafat adalah "cinta kebijaksanaan". Filsafat adalah ilmu yang mempelajari dengan sungguhsungguh tentang hakekat kebenaran sesuatu. Dalam filsafat, pemahaman manusia dilihat dari berbagai sudut pandang, yaitu: pertama, masalah rohani dan jasmani; Aliran Serba zat (Faham Materialisme), Aliran Serba Ruh, Aliran Dualisme, dan Aliran Eksistensialisme. Kedua, sudut pandang antropologi; manusia sebagai makhluk individu (individual being), manusia sebagai makhluk sosial (sosial being) dan manusia sebagai makhluk susila (moral being). Ketiga, pandangan Freud tentang struktur jiwa (kepribadian); bagian dasar atau das Es (the Id), bagian tengah atau das Ich (aku) dan bagian atas atau das Uber Ich (superego). Keempat, sudut pandang asal-mula dan tujuan hidup manusia; kehidupan ini berawal dari causa prima (Tuhan) dan pada akhirnya kembali kepada causa prima (Tuhan) pula. Hubungan antara manusia, filsafat dan pendidikan terletak pada; filsafat digunakan untuk mencari hakekat manusia, sehingga diketahui apa saja yang ada dalam diri manusia. Hasil kajian dalam filsafat tersebut oleh pendidikan dikembangkan dan dijadikannya (potensi) nyata berdasarkan esensi keberadaan manusia. Demikian semoga bermanfaat. 


\section{Referensi}

وما . خلقت الجن و الانس الا ليعبدون

2Kasdin Sihotang, Filsafat Manusia Upaya Membangkitkan Humanisme, (Yogyakarta: Pustaka Filsafat, 2009), hlm. 19.

${ }^{3}$ Bdk. Andre Ata Ujan, Filsafat Hukum: Membangun Hukum, Memebela Keadilan, (Yogyakarta: Kanisius, 2008), hlm. 15-16. Dalam Kasding Sihotang, Filsafat Manusia... hlm. 20.

IIbid.., hlm. 21.

5 Pengertian ini sejalan dengan pengertian kata "kritik" yang sebenarnya. Secara etimologis kata kritik berasal dari bahasa Yunani "kritikos", yang berarti mampu membedakan dan mengambil keputusan. Dalam bahasa Latin terdapat kata "criticus" yang diturunkan dari kata kerja "cernere", yang berarti membedakan, mengerti dan memutuskan

6Ibid.., hlm. 21.

7Suparlan Suhartono, Filsafat Pendidikan, (Yogyakarta: Ar-Ruzz Media, 2007), hlm. 37-38.

8 Jalaludin dan Abdulloh, Filsafat Pendidikan, (Jakarta: Gaya Media Pratama, 1997), hlm. 11.

${ }^{9}$ Hamdani Ihsan dan Fuad Ihsan, Filsafat Pendidikan Islam, (Bandung: Pustaka Setia, 2007), hlm.9.

${ }^{10}$ Ibid, hal 13.

${ }^{11}$ Acuan tulisan ini terdapat dalam Brettal R., 1947, A Kiergegaard Anthology, Princeton: Princeton University Press, Mary Warnock, 1979, Existentialism, Ocxfard University Press, dan E.L. Allen, 1953, Existentialims From Within, London: Routledge \& Kegan Paul, Ltd. Dalam Zaenal Abidin, Fulsafat Manusia Memahami Manusia Melalui Filsafat, (Bandung: Remaja Rosdakarya, 2011), hlm. 143.

12Zaenal Abidin, Filsafat Manusia Memahami Manusia Melalui Filsafat, (Bandung: Remaja Rosdakarya, 2011), 148-149.

13Ibid.., hlm. 150.

14Ibid.., hlm. 151.

15Ibid, hal. 49.

16Jalaludin dan Abdulloh, Filsafat Pendidikan,

(Jakarta: Gaya Media Pratama, 1997), hlm. 107.

1717Ibid.., hlm.107.

${ }^{18}$ Mohammad Noor Syam, Filsafat Pendidikan dan Dasar Filsafat Pendidikan Pancasila, (Surabaya: Usaha Nasional, 1988 cet.4), hlm. 163.
19Jalaludin dan Abdulloh, Filsafat Pendidikan, (Jakarta: Gaya Media Pratama, 1997) hlm. 107.

20Mohammad Noor Syam, Filsafat Pendidikan dan Dasar Filsafat Pendidikan Pancasila, (Surabaya: Usaha Nasional, 1988 cet.4), hlm. 164.

21Jalaludin dan Abdulloh, Filsafat Pendidikan, (Jakarta: Gaya Media Pratama, 1997) hlm. 108.

22Mohammad Noor Syam, Filsafat Pendidikan dan Dasar Filsafat Pendidikan Pancasila, (Surabaya: Usaha Nasional, 1988 cet.4), hlm. 165.

23Ibid. hlm. 166.

24Jalaludin dan Abdulloh, Filsafat Pendidikan, (Jakarta: Gaya Media Pratama, 1997), hlm. 108. 25Mohammad Noor Syam, Filsafat Pendidikan dan Dasar Filsafat Pendidikan Pancasila, (Surabaya: Usaha Nasional, 1988 cet.4), hlm. 170.

26Ibid.., hlm. 175.

27Ibid.., hlm. 175-176.

28Ibid.., hlm. 158-160.

29Suparlan Suhartono, Filsafat Pendidikan,

(Yogyakarta: Ar-Ruzz Media, 2007), hlm. 61-62.

30Ibid.., hlm. 62.

31Ahmad Janan Asifudin, Mengungkit Pilar-

pilar Pendidikan Islam (Tinjauann Filosofis),

(Yogyakarta: Suka Press, 2009), hlm. 49-50.

32Zaenuddin Ali, Pendidikan Agama Islam,

(Jakarta: Bumi Aksara, 2010), hlm. 18.

33Ibid.., hlm. 19.

${ }^{34}$ Harun Nasution, Islam Rasional, (Bandung:

Mizan, 1995), hlm. 38. Dalam Zaenuddin, ibid.., hlm. 19.

35Ibid.., hlm. 22.

36Pengertian dari Ibu Susilaningsih, Dosen Pengampu Mata Kuliah Psikologi, ketika proses belajar mengajar di UIN Sunan Kalijaga Yogyakarta.

37Hamdani Ihsan dan Fuad Ihsan, Filsafat Pendidikan Islam, (Bandung: Pustaka setia, 2007), hlm. 59.

38Suparlan Suhartono, Filsafat Pendidikan, (Yogyakarta: Ar-Ruzz Media, 2007), hlm. 62.

${ }^{39}$ Ibid.., hlm. 56.

40Mohammad Noor Syam, Filsafat Pendidikan dan Dasar Filsafat Pendidikan Pancasila, (Surabaya: Usaha Nasional, 1988 cet.4), hlm. 160-161. 